Tropical Journal of Pharmaceutical Research, June 2009; 8 (3): 193-200

(C) Pharmacotherapy Group,

Faculty of Pharmacy, University of Benin

Benin City, 300001 Nigeria.

All rights reserved.

Research Article

Available online at http://www.tjpr.org

\title{
Assessment of the Extracts of Centaurea tchihatcheffii Fischer for Anti-inflammatory and Analgesic Activities in Animal Models
}

\author{
Ufuk Koca, Gülnur Toker and Esra Küpeli Akkol
}

Department of Pharmacognosy, Faculty of Pharmacy, Gazi University, Etiler 06330, Ankara, Turkey

\begin{abstract}
Purpose: To evaluate the ethanol extracts of the flowers, leaves, and stems of Centaurea tchihatcheffii Fischer \& C.A. Meyer (Asteraceae) for their anti-inflammatory and analgesic activities in male Swiss albino mice.

Methods: For the evaluation of anti-inflammatory activity, hind paw oedema was induced in the mice with carrageenan and prostaglandin- $E_{2}\left(P G E_{2}\right)$ and the mice received either 100 and $200 \mathrm{mg} / \mathrm{kg}$ body weight doses of the flower extract or $200 \mathrm{mg} / \mathrm{kg}$ body weight dose of the leaf and stem extracts. Furthermore, ear oedema was induced in other groups of mice with 12-O-tetradecanoyl-13-acetate (TPA) and then administered with $0.5 \mathrm{mg} / \mathrm{ear}$ dose of the extract of either of the three plant parts. In order to evaluate analgesic activity, p-benzoquinone-induced abdominal constriction test was used with 100,200 and $400 \mathrm{mg} / \mathrm{kg}$ body weight doses of the flower or $200 \mathrm{mg} / \mathrm{kg}$ body weight dose of the leaf and stem extracts administered. Indomethacin and acetylsalicylic acid were the reference drugs for antiinflamatory and analgesic evaluations, respectively. Phytochemical screening of the flower extract was carried out by thin layer chromatography (TLC).

Results: The results of evaluation of the anti-inflammatory activities induced by carrageenan and $P G E_{2}$ showed that the flower extract diminished cyclo-oxygenase activitiy at the $200 \mathrm{mg} / \mathrm{kg}$ dose to the same level as the reference drug, indomethacin. However, no anti-inflamatory activity was seen in the TPAinduced ear oedema model. The extracts from all three parts of the plant showed analgesia in $p$ benzoquinone-induced abdominal constriction test. TLC analysis of the flower extract indicated the presence of sesquiterpen lactones, which may have been responsible for the analgesic activity.

Conclusion: Our results support the use of $C$. tchihatcheffii in traditional medicine in Turkey for their anti-inflammatory and analgesic properties.
\end{abstract}

Keywords: Centaurea tchihatcheffii, leaves, flowers, stems, anti-inflammatory, analgesic.

${ }^{*}$ Corresponding author: E-mail: esrak@gazi.edu.tr; Fax:+90-312-2235018 


\section{INTRODUCTION}

The Mediteranean region is highly rich in Centaurea (Asteraceae) species. Although, more than 700 species are found in the region, only about 178 of them grow in Turkey ${ }^{1}$. Besides their attractive flowers, many of the Centaurea genuses have significant applications in traditional medicine. For instance, the dried flowers of Centaurea cyanus $L$. are used as a $5 \%$ infusion to ease the symptoms of diarrhoea, as well as to gain energy, increase appetite, and relieve chest tightness ${ }^{2-3}$. Centaurea behen $\mathrm{L}$. is used for alleviating stomach problems and initiating menstruation ${ }^{4}$ while Centaurea calcitrapa $\mathrm{L}$. is used as a $2-6 \%$ infusion for the relief of fever and Centaurea iberica Trev. ex Spreng for relieving abdominal pains and as a remedy for insect and snake bites ${ }^{4}$. Also, most of the Centaurea species have been used individually or in combination with some plants for the folkloric treatment of diabetes, rheumatism and inflammation ${ }^{5-6}$. In addition to these traditional uses, the species have also found use for their choleretic, digestive,, diuretic, astringent, hypotensive, antipyretic, cytotoxic, and antibacterial effects ${ }^{7-10}$.

In this study, the anti-inflammatory and analgesic properties of $C$. tchihatcheffii Fischer \& C.A. Meyer have been evaluated using rodent models.

\section{MATERIALS AND METHODS}

\section{Plant material and preparation of extracts}

C. tchihatcheffii plant samples were collected from the Gölbasi district of Ankara during the month of May, 2007. The plant was authenticated by Prof. Dr. Mecit Vural of the Department of Biology, Faculty of Art and Science, Gazi University, Ankara, Turkey. A specimen of the original collection was placed in the herbarium of the Faculty of Pharmacy, Gazi University, Ankara, Turkey (Herbarium no. 2592).
The plant materials, comprising of leaves, flowers and stems were air-dried at room temperature and powdered by using a pestle and mortar. Thereafter, $10 \mathrm{~g}$ each of the leaves, flowers, and stems of $C$. tchihatcheffii was extracted separately with $3 \times 200 \mathrm{ml}$ $80 \%$ ethanol $(\mathrm{EtOH})$ at room temperature overnight. In each case, the pooled extract was evaporated to dryness in vacuo using a rotary evaporator at $40{ }^{\circ} \mathrm{C}$ to give a yield of $38.5 \%$ (flowers), $39.2 \%$ (leaves) and $35.0 \%$ (stem).

\section{Drugs and chemicals}

Carrageenan (Sigma, St. Louis, Missouri, USA), $\mathrm{PGE}_{2}$ (Fluka Chemie AG), 12-Otetradecanoyl-13-acetate (TPA) (SigmaAldrich, St.Louis, USA), p-benzoquinone (Merck), indomethacin (Bayer AG), acetylsalicylic acid (Bayer AG), sodium carboxymethylcellulose (Aldrich Steinheim, Germany), absolute ethanol (Merck) were used as drugs and/or chemicals.

The plant extracts were suspended in a mixture of distilled $\mathrm{H}_{2} \mathrm{O}$ and $0.5 \%$ sodium carboxymethyl cellulose (CMC) and given to the test animals by mouth. The control group received the same treatment as the test groups except that the drug was replaced with an appropriate volume of vehicle. Indomethacin (10 mg/kg and $0.5 \mathrm{mg} / \mathrm{ear}$ ) and acetylsalicylic acid (ASA; $200 \mathrm{mg} / \mathrm{kg}$ ) in $0.5 \%$ $\mathrm{CMC}$ were used as reference drugs.

\section{Animals}

Male Swiss albino mice (20-25 g) were purchased from the animal breeding laboratories of Refik Saydam Central Institute of Health, Ankara, Turkey. The animals were left for two days, to acclimatize to ambient conditions, maintained on standard pellet diet and given water ad libitum. The food was withdrawn on the day before the experiment; however, they were allowed free access to water. Throughout the experiments, the animals were handled according to the prescribed ethical guidelines of Gazi 
University Ethical Council Project Number: G.Ü.ET-05.004 for the care of laboratory animals.

In preliminary experiments, $200 \mathrm{mg} / \mathrm{kg}$ dose extract of either the flowers, leaves or stems were tested on the animals. At this dose, the leaf and stem extracts were not effective except for the flower extract. Therefore, a dose - response was established by administering half and twice the above dose, respectively.

\section{Anti-inflammatory tests}

\section{Carrageenan-induced hind paw oedema model}

Carrageenan-induced hind paw oedema model was used for the determination of antiinflammatory activity ${ }^{11}$. Six animals were used for each extract dose, as well as the control and reference groups. For flower extract,, 100 and $200 \mathrm{mg} / \mathrm{kg}$ doses were administered while for the stem and leaf extract, only $200 \mathrm{mg} / \mathrm{kg}$ dose was given one hour after oral administration of the extract/drug or vehicle, the subplantar tissue of right hind paw of each mouse was injected (Hamilton ${ }^{\circledR}$ microsyringe) with $25 \mu \mathrm{l}$ of 20 $\mathrm{mg} / \mathrm{ml}$ of freshly prepared carrageenan in physiological saline $(0.9 \% \mathrm{NaCl})$. For control purposes, $25 \mu \mathrm{l}$ of saline was injected into subplantar tissue of left hind paw. Thereafter, paw edema was measured at $1.5 \mathrm{~h}$ interval for $6 \mathrm{~h}$. The difference of thickness in footpad was measured with calipers (Ozaki Co., Tokyo, Japan). Indomethacin (10 mg/kg) was used as the reference drug.

\section{$P G E_{2}$-induced hind paw oedema model}

$\mathrm{PGE}_{2}$-induced hind paw edema model was also used for the determination of antiinflammatory activity following the method described by Kasahara et $\mathrm{al}^{12}$. Six animals per group were were given either an extract, control and reference drug (indomethacin, 10 $\mathrm{mg} / \mathrm{kg}$ ). The extract dose was $200 \mathrm{mg} / \mathrm{kg}$ for each of the plant extract. One hour after oral administration of an extract, drug or vehicle (control), each mouse received $5 \mu \mathrm{l}$ of freshly prepared suspension of $\mathrm{PGE}_{2}(1 \mathrm{mg} / \mathrm{ml})$ in Tyrode's solution by injection into the subplantar tissue of the right hind paw except that for control, $5 \mu$ of Tyrode's solution was injected into the left hind paw. Thereafter, paw edema was measured at 15 min interval for $75 \mathrm{~min}$. The difference in the thickness of the footpad was measured as earlier described.

\section{TPA-induced mouse ear oedema}

Each mouse received $20 \mu \mathrm{l}$ of $125 \mu \mathrm{g} / \mathrm{ml}$ of TPA dissolved in $70 \% \mathrm{EtOH}^{13}$. Six animals were used for each group, namely, each of the extracts, control and reference groups. For the extracts and reference drug, 0.5 mg/ear dose was applied by a pipette to both anterior and posterior surfaces of the right ear. The same volume of solvent $(70 \% \mathrm{EtOH})$ was applied to the left ear which served as control. Anti-inflammatory activity was determined by two different methods. First, the thickness of each ear was measured $4 \mathrm{~h}$ after induction of inflammation with calipers and the level of oedema was expressed as the difference in thickness between the right and left ears. Inhibition (\%) was expressed as a reduction in thickness with respect to the control. In the second method, the animals were killed under deep ether anesthesia $4 \mathrm{~h}$ after drug/extract administration. Discs of 6 $\mathrm{mm}$ diameter were removed from each ear and weighed. The swelling was estimated as the difference in weight between the discs cut from the right and left ears, which was expressed as increase in ear thickness.

\section{Analgesic test}

p-Benzoquinone - induced abdominal constriction test ${ }^{14}$ was performed on mice in order to determine analgesic activity. Six animals were used for each of the following groups: each extract, control (distilled water) and reference drug (ASA, $200 \mathrm{mg} / \mathrm{kg}$ ). For the extracts, the doses administered were $100,200,400 \mathrm{mg} / \mathrm{kg}$ doses (flower) and 200 
$\mathrm{mg} / \mathrm{kg}$ (leaf and stem). One hour after oral administration of an extract, drug, or reference drug, the mice were given intraperitoneal injections of $0.1 \mathrm{ml} / 10 \mathrm{~g}$ body weight of $2.5 \% \mathrm{w} / \mathrm{v}$ of solution of $p$ benzoquinone (PBQ) in distilled water. The mice were then observed individually $5 \mathrm{~min}$ after $\mathrm{PBQ}$ injection for the number of abdominal contractions (writhing movements) for a period of $15 \mathrm{~min}$.

The mice were killed under deep ether anesthesia and the stomach of each mouse was removed, opened through the greater curvature and examined under a dissecting microscope for lesions or bleedings.

\section{Statistical analysis of data}

Data obtained from animal experiments were expressed as mean \pm S.E.M (standard error of the mean). Statistical differences between the treated and the control groups were evaluated by ANOVA and Students-NewmanKeuls post-hoc tests. $p<0.05$ was considered significant.

\section{RESULT}

Table 1 shows the dose - response data of the extracts with regard to $p$-benzoquinoneinduced abdominal constriction). All the animals died within $2 \mathrm{~h}$ following the administration of $400 \mathrm{mg} / \mathrm{kg}$ dose of the flower extract but no effect was observed at $100 \mathrm{mg} / \mathrm{kg}$ dose. Consequently, $200 \mathrm{mg} / \mathrm{kg}$ dose was selected for further experiments. Although the leaf and stem extracts did not exert any meaningful analgesic effect, the flower extract $(200 \mathrm{mg} / \mathrm{kg}$ dose) significantly inhibited $(35.3 \%)$ abdominal constriction in the mice. Furthermore, no ulceration was observed in stomach of the animals following the administration of the flower extract.

Flower extracts displayed significant inhibition $(24.8-34.0 \%)$ at dose of $200 \mathrm{mg} / \mathrm{kg}$ also in carrageenan-induced hind paw oedema compared to the other extracts (Table 2). In this regard the inhibitory effect of the flower extract (34\%) was close to that of indomethacin (38.7\%) after $270 \mathrm{~min}$.

The results of the anti-inflammatory effect of the extracts on hind-paw oedema induced by prostaglandin $E_{2}$ are indicated in Table 3 . This time measurements were kept between 0-60 min. with 15 min intervals. The extract of flowers considerably inhibited (23.2 - $27.2 \%$ inhibition) hind-paw oedema while the leaf and stem extracts did not demonstrate a notable activity (Table 3 ). Maximum inhibition (27.2 \%) by the flower extract was observed after 45 min which decreased thereafter. The reference drug (indomethacin) presented a similar trend, peak at $38 \%$ inhibition after 45 $\min$.

As shown in Table 4, while indomethacin exhibited $74.5 \%$ inhibition on swelling thickness and $38.9 \%$ inhibition on weight edema, the flower extract displayed only 20.6 and $12 \%$ inhibition, respectively, thus indicating that the plant parts did not show remarkable anti-inflammatory activity in the TPA-induced experimental model.

\section{DISCUSSION}

Subcutaneous injection of carrageenan into the rat paw produces plasma extravasation and inflammation that are characterized by elevated tissue water and plasma protein exudation with neutrophil extravasation, in addition to increased metabolism of arachidonic acid by both cyclo-oxygenase and lipoxygenase enzyme pathways ${ }^{15-16}$. There are biphasic effects in carrageenaninduced oedema. The first phase begins immediately after injection and diminishes in $1 \mathrm{~h}$. The second phase begins in an hour and remains through $3 \mathrm{~h}^{17}$. It is suggested that the early hyperemia of carrageenan-induced oedema results from the release of histamine and serotonin ${ }^{18}$. On the other hand, the delayed phase of carrageenan-induced oedema results mainly from the potentiating effect of prostaglandins on mediator release, particularly bradykinin. Hydrocortisone and 
Table 1: Effect of the extracts of various parts of $C$. tchihatcheffii on $p$-benzoquinone-induced writhings in mice

\begin{tabular}{lcccc}
\hline Extract/ Drug & $\begin{array}{c}\text { Dose } \\
(\mathrm{mg} / \mathrm{kg})\end{array}$ & Number of writhings \pm SEM & $\begin{array}{c}\text { Inhibition } \\
\text { ratio (\%) }\end{array}$ & $\begin{array}{c}\text { Ratio of } \\
\text { ulceration }\end{array}$ \\
\hline Control & - & $42.2 \pm 4.8$ & - & $0 / 6$ \\
Leaf & 200 & $44.3 \pm 3.3$ & 6.9 & $0 / 6$ \\
& 100 & $39.3 \pm 2.7$ & 35.3 & $0 / 6$ \\
Flower & 200 & $27.3 \pm 2.4^{\star *}$ & --- & $\mathrm{a}$ \\
Stem & 400 & $45.2 \pm 1.4$ & --- & $1 / 6$ \\
ASA & 200 & $52.3 \pm 1.9$ & 54.3 & $4 / 6$ \\
\hline
\end{tabular}

${ }^{*}: p<0.05 .{ }^{* *}: p<0.01 .{ }^{* * *}: p<0.001$ (compared to control, $n=6$ )

a The animals died in $2 h$; therefore, ratio of ulceration could not be determined

Table 2: Effect of the extracts of different parts of $C$. tchihatcheffii on carrageenan-induced paw edema in mice

\begin{tabular}{|c|c|c|c|c|c|c|c|c|c|c|c|c|}
\hline \multirow{2}{*}{\multicolumn{2}{|c|}{$\begin{array}{l}\text { Extract// } \\
\text { Drug }\end{array}$}} & \multirow{2}{*}{$\begin{array}{l}\text { Dose } \\
\text { (mg/kg) }\end{array}$} & \multicolumn{3}{|c|}{$90 \mathrm{~min}$} & \multicolumn{2}{|l|}{$180 \mathrm{~min}$} & \multicolumn{2}{|c|}{$270 \min$} & \multicolumn{3}{|c|}{$360 \min$} \\
\hline & & & \multicolumn{2}{|c|}{$\begin{array}{l}\text { Swell. thick. } \\
\pm \text { SEM }\end{array}$} & $\begin{array}{l}\text { Inh. } \\
\%\end{array}$ & $\begin{array}{l}\text { Swell. thick. } \\
\pm \text { SEM }\end{array}$ & $\begin{array}{l}\text { Inh. } \\
\%\end{array}$ & $\begin{array}{l}\text { Swell. } \\
\text { thick. } \pm \\
\text { SEM }\end{array}$ & $\begin{array}{l}\text { Inh. } \\
\%\end{array}$ & \multicolumn{2}{|c|}{$\begin{array}{l}\text { Swell. } \\
\text { thick. } \pm \\
\text { SEM }\end{array}$} & $\begin{array}{l}\text { Inh. } \\
\%\end{array}$ \\
\hline \multicolumn{2}{|l|}{ Control } & & \multicolumn{2}{|c|}{$43.2 \pm 3.9$} & 0 & $55.2 \pm 3.5$ & - & $60.5 \pm 2.3$ & - & \multicolumn{2}{|c|}{$64.3 \pm 4.5$} & \\
\hline \multicolumn{2}{|l|}{ Leaf } & 200 & \multicolumn{2}{|c|}{$40.8 \pm 3.7$} & 5.6 & $49.8 \pm 2.3$ & 9.8 & $54.8 \pm 3.1$ & 9.4 & \multicolumn{2}{|c|}{$60.2 \pm 3.1$} & 6.4 \\
\hline \multirow{2}{*}{\multicolumn{2}{|c|}{ Flower }} & 100 & \multicolumn{2}{|c|}{$41.7 \pm 4.3$} & 3.5 & $51.6 \pm 4.9$ & 6.5 & $59.1 \pm 3.6$ & 2.3 & \multicolumn{2}{|c|}{$61.2 \pm 4.7$} & 4.8 \\
\hline & & 200 & \multicolumn{2}{|c|}{$34.7 \pm 3.2$} & 19.7 & $41.5 \pm 2.1$ & $24.8^{*}$ & $39.9 \pm 4.1$ & $34.0^{\star *}$ & 44.2 & $2 \pm 2.2$ & $31.3^{* *}$ \\
\hline Stem & & 200 & 40.5 & \pm 4.5 & 6.3 & $51.2 \pm 3.2$ & 7.2 & $58.2 \pm 4.9$ & 3.8 & 55.3 & $3 \pm 3.4$ & 13.9 \\
\hline Indomet & hacin & 10 & $34.0=$ & \pm 3.1 & 21.3 & $35.3 \pm 1.9$ & $36.1^{* \star}$ & $37.1 \pm 2.1$ & $38.7^{\star \star \star}$ & 39.9 & $9 \pm 1.8$ & $37.9^{* *}$ \\
\hline $\begin{array}{l}\text { Swell. th } \\
*: p<0.05\end{array}$ & ick. $=S$ & welling & hicknes & ss $\left(\times 10^{-2}\right.$ & $\left.{ }^{2} \mathrm{~mm}\right)$ & $\begin{array}{l}S E M=\text { standar } \\
\text { to control, } n=6 \text { ) }\end{array}$ & rd erro & r mean; Inh & 7. = Inhibi & & & \\
\hline & & & & & & hatcheffii on $\mathrm{PC}$ & $\mathrm{GE}_{2}$-ir & 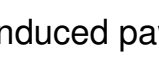 & w edem & & mice & \\
\hline Extract/ & Dose & $0 \mathrm{~m}$ & & $15 \mathrm{~m}$ & & $30 \mathrm{~min}$ & & $45 \min$ & $60 \mathrm{mi}$ & & $75 \mathrm{~m}$ & $\min$ \\
\hline Drug & $(\mathrm{mg} / \mathrm{kg})$ & $\begin{array}{l}\text { Swell. } \\
\text { thick. } \pm \\
\text { SEM }\end{array}$ & $\begin{array}{l}\text { Inh. } \\
\%\end{array}$ & $\begin{array}{l}\text { Swell. } \\
\text { thick. } \pm \\
\text { SEM }\end{array}$ & $\begin{array}{l}\text { Inh. } \\
\%\end{array}$ & $\begin{array}{l}\text { Swell. Inh. } \\
\text { thick. } \pm \quad \% \\
\text { SEM }\end{array}$ & $\begin{array}{l}\text { Swell } \\
\text { thick. } \\
\text { SEM }\end{array}$ & $\begin{array}{l}\text { Inh. } \\
\pm \quad \%\end{array}$ & $\begin{array}{l}\text { Swell. } \\
\text { thick. } \pm \\
\text { SEM }\end{array}$ & $\begin{array}{l}\text { Inh. } \\
\%\end{array}$ & $\begin{array}{l}\text { Swell. } \\
\text { thick. } \pm \\
\text { SEM }\end{array}$ & $\begin{array}{l}\text { Inh. } \\
\%\end{array}$ \\
\hline Control & & $1.5 \pm 0.9$ & - & $11.4 \pm 1.5$ & 5 & $20.3 \pm 1.9$ & $27.6 \pm$ & & $25.9 \pm 2.5$ & - & $19.7 \pm 1.6$ & - \\
\hline Leaf & 200 & $1.6 \pm 0.7$ & - & $15.8 \pm 1.1$ & 1 & $24.7 \pm 1.4$ & $29.5 \pm$ & 1.7 & $31.7 \pm 2.4$ & - & $27.6 \pm 1.8$ & 8 \\
\hline Flower & 200 & $1.5 \pm 0.8$ & - & $13.1 \pm 1.3$ & - & $15.6 \pm 1.123 .2^{*}$ & $20.1 \pm$ & $\pm 1.427 .2^{*}$ & $20.1 \pm 1.2$ & 19.7 & $17.6 \pm 1.4$ & 410.7 \\
\hline Stem & 200 & $1.7 \pm 0.9$ & - & $10.2 \pm 1.4$ & 410.5 & $19.7 \pm 1.6 \quad 2.9$ & $29.2 \pm$ & 2.3 & $27.6 \pm 2.7$ & - & $20.3 \pm 2.1$ & - \\
\hline $\begin{array}{l}\text { Indome- } \\
\text { thacin }\end{array}$ & 10 & $1.5 \pm 0.6$ & - & $9.8 \pm 1.3$ & 14.0 & $13.9 \pm 1.431 .5^{* \star}$ & $17.1 \pm$ & $\pm 1.338 .0^{* \star}$ & $20.4 \pm 1.1$ & $21.2^{*}$ & $16.8 \pm 1.5$ & 514.7 \\
\hline
\end{tabular}

Swell. thick. = Swelling thickness $\left(\times 10^{-2} \mathrm{~mm}\right) ;$ SEM = standard error mean, Inh. = Inhibition.

${ }^{*}: p<0.05 .{ }^{* *}: p<0.01$. ${ }^{* *}: p<0.001$ (compared to control, $n=6$ ); 
Koca et al

Table 4: Effect of the extracts of $C$. tchihatcheffii against TPA-induced ear edema in mice

\begin{tabular}{lccccc}
\hline Extract & $\begin{array}{c}\text { Dose } \\
(\mathrm{mg} / \mathrm{ear})\end{array}$ & $\begin{array}{c}\text { Swelling thickness } \\
(\mu \mathrm{m}) \pm \text { S.E.M }\end{array}$ & Inhibition \% & $\begin{array}{c}\text { Weight edema } \\
(\mathrm{mg}) \pm \text { S.E.M }\end{array}$ & Inhibition \% \\
\hline Control & - & $211.9 \pm 40.7$ & & $31.6 \pm 7.3$ & \\
Folia & 0.5 & $199.4 \pm 28.9$ & 5.9 & $35.1 \pm 6.5$ & -- \\
Flowers & 0.5 & $168.2 \pm 31.5$ & 20.6 & $27.8 \pm 5.1$ & 12.0 \\
Stem & 0.5 & $236.7 \pm 45.2$ & --- & $37.5 \pm 8.3$ & -- \\
Indomethacin & 0.5 & $54.1 \pm 23.0$ & $74.5^{\text {***}}$ & $19.3 \pm 5.2$ & $38.9^{\text {***}}$ \\
\hline
\end{tabular}

${ }^{*}: p<0.05 .{ }^{* *}: p<0.01 .{ }^{* * *}: p<0.001 ;$ S. E.M: standard error mean

some NSAIDs inhibit strongly the second phase of carrageenan-induced oedema ${ }^{19}$. Flowers of $C$. tchihatcheffii seemed effective in both phases of acute inflammation. Therefore, C. tchihatcheffii may block prostaglandin and/or bradykinin release, and histamine and/or serotonin.

Although the TPA model has limited selectivity in determining the possible mechanism of action, it is appropriate for assessing antiinflammatory effects in a first stage trial. It has been established that this agent exerts its inflammatory effect through protein kinase C activation with the subsequent cytosolic phospholipase $\mathrm{A}_{2}$ stimulation, AA mobilization, and biosynthesis of prostaglandins and leukotrienes ${ }^{20}$.

In contrast with the results obtained in the carrageenan-induced hind paw oedema model, the flower extract failed to inhibit ear oedema. This may be due to the different mechanisms of action of the phlogistic agents or to the fact that the systemic route of administration failed to achieve adequate concentration of the compounds at the site of inflammation.

In a earlier study, 2-methylpropanoate and 2methyl-2-propenoate of 11, 13-dehydromelitensin, were isolated from the aerial parts of $C$. chilensis. The mixture of both substances exhibited anti-inflammatory activity in the carrageenan-induced paw edema assay ${ }^{21}$. A $20 \%$ infusion, administered orally at a dose of $4 \mathrm{ml} / \mathrm{kg}$, exhibited a mild inflammatory activity on laboratory animals while 400 and $600 \mathrm{mg} / \mathrm{kg}$ doses of the methanol extract with propylene-glycol as the solvent produced 29 and $49 \%$ inhibition, respectively. Naproxen-sodium (4.3 mg/kg), used as a reference, showed $58 \%$ inhibitions. According to these results, the extracts of $C$. chilensis were at least as effective as other synthetic inflammatory compounds due to the presence of sesquiterpene lactones (notably $\alpha$-methylene- $y$-lactone) but less effective than naproxen.

The presence of orally effective antiinflammatory sesquiterpene lactones clarifies the traditional use of these plants to heal inflammatory diseases ${ }^{18}$. These results are valuable since $C$. chilensis is from the same family as $C$. tchihatcheffii and might contain the compounds. Our unpublished chromatographic studies on the flower extracts of $C$. tchihatcheffii show that it contains sesquiterpene lactones.

Garbacki et al studied the anti-inflammatory properties of polysaccharides extracted from C. cyanus flower heads ${ }^{22}$. These polysaccharides were found to be primarily composed of galacturonic acid, arabinose, glucose, rhamnose and galactose. Fractions, soluble only in water, as well as those soluble in both water and ethanol were effective against carrageen-induced oedema; however, the fraction, which was insoluble in ethanol, was more effective. This fraction showed $69 \%$ inhibition of carrageen-induced oedema at a 
dose of $60 \mathrm{mg} / \mathrm{kg}$ and $52 \%$ inhibition of croton oil-induced edema at $800 \mu \mathrm{g} / \mathrm{ear}$ topical administration $^{22}$.

A study has asserted that the antiinflammatory effect of the compound, centaureidin, is the result of inhibition of the activities related to lipoxygenases and cyclooxygenase in the path ${ }^{7}$. Another study has demonstrated the anti-inflammatory effects of C. hierapolitana, C. calolepis and C. cadmea in vitro. The extracts of these plants exhibited strong anti-inflammatory activities by inhibiting their effects on the activation of the transcription factor, NF-kappa $B^{23}$. These authors also declared that a good number of Centaurea species frequently contain sesquiterpene lactone derivatives and flavonoid derivatives and thus their activity might come from the effects of these phytochemicals.

\section{CONCLUSION}

The analgesic and anti-inflammatory activities of leaf and stem extracts of $C$. tchihatcheffii were found to be statistically insignificant but the flower extract showed these significant biological activities without inducing any apparent acute toxicity as well as gastric damage at a dose of $200 \mathrm{mg} / \mathrm{kg}$ body weight. This suggests that $C$. tchihatcheffii may reduce the risk of inflammation-related diseases and thus supports the folkloric of most of the Centaurea species for inflammatory conditions. However, further studies need to be conducted in order to clarify which constituent(s) of the extract is/are responsible for these activities.

\section{ACKNOWLEDGEMENT}

The authors are thankful to Prof. Dr. Mecit Vural (Gazi University, Faculty of Science, Etiler, Ankara, Turkey) for the authentication of the plant specimen.

\section{REFERENCES}

1. Seçmen Ö, Gemici Y, Görk G, Bekat L, Leblebici E. Systematics of Seed Plants. Bornova, Izmir, Turkey, Aegean University Press, 1995, pp 301-396, (In Turkish).

2. Wagenitz G. Centaurea L. In: Flora of Turkey and The East Aegean Islands, Ed. Davis, P.H V, Edinburgh, Edinburgh University Press, 1975, pp 465-586.

3. Baytop T. Therapy with Medicinal Plants in Turkey (Past and Present), $2^{\text {nd }}$ Edition, Istanbul, Nobel Tıp Basımevi, 1999, pp.316.

4. Erol MK, Tuzlacı, E. Plants used in folk medicine in the region of Eğirdir (Isparta) "XI.th Meeting on plant drug active constituents' Ed. Coşkun, M, Ankara University Pharmacy Faculty No:75, Ankara, Ankara Universitesi Basımevi, 1997, pp. 466-475.

5. Chucla MT, Lamela M, Gato A, Cadavid I. Centaurea corcubionensis: A study of its hypoglycemic activity in rats. Planta Med, 1988; 107-109.

6. Talhouk RS, El-Jouni W, Baalbaki R, Gali-Muhtasib H, Kogan J, Talhouk AN. Anti-inflammatory bioactivities in water extract of Centaurea ainetensis. J Med Plants Res, 2008; 2:24-33.

7. Orallo $F$, Lamela M, Camina M, Uriatre E, Calleja M. Preliminary study of the potential vasodilator effects on rat aorta of centaurein and centaureidin, two flavonoids from Centaurea corcubionensis. Planta Med, 1998; 64:116-119.

8. Barrero AF, Herrador MM, Arteaga P, Cabrera E, Rodriguez-Garcia I, Garcia-Moreno M, Gravalos DG. Cytotoxic activity of flavonoids from Carthamus arborescens, Ononis natrix ssp. ramosissima and Centaurea malacitana. Fitoterapia, 1997; 68:281-283.

9. Gürkan E, Sarıoğlu I, Oksüz S. Cytotoxicity assay of some plants from Asteraceae. Fitoterapia, 1998; 69:81-82.

10. Wei HX, Gao WY, Tian YK, Guan YK, Huang MH, Cheng DL. New eudesmane sesquiterpene and thiophene derivatives from the roots of Rhaponticum uniflorum. Pharmazie, 1997; 52:245-247.

11. Yeşilada E., Küpeli E. Berberis crategina DC. Root exhibits potent anti-inflammatory, analgesic and febrifuge effects in mice and rats. $J$ Ethnopharmacol, 2002; 79: 237-248.

12. Kasahara $Y$, Hikino $H$, Tsurufiji $S$, Watanabe $M$, Ohuchi K. Antiinflammatory actions of ephedrines in acute inflammations. Planta Med, 1985; $51: 325-331$.

13. De Young LM, Kheifets JB, Ballaron SJ, Young JM. Edema and cell infiltration in the phorbol ester treated mouse ear are temporally separate and can be differently modulated by pharmacologic agents. Agents and Action, 1989; 26:335-341.

14. Okun $R$, Liddon SC, Lasagnal $L$. The effect of aggregation, electric shock and adrenergic bloking drugs on inhibition of the "writhing 
syndrome". J Pharmacol Exp Ther, 1963; 139:107-109.

15. Szolcsanyi J, Helyes Z, Oroszi G, Nemeth J, Pinter E. Release of somatostatin and its role in the mediation of the anti-inflammatory effect induced by antidromic stimulation of sensory fibres of rat sciatic nerve. $\mathrm{Br} J$ Pharmacol, 1998; 123:936-942

16. Gamache DA, Povlishock JT, Ellis EF. Carrageenan induced brain inflammation, characterization of the model. J Neurosurg, 1986; 65:679-685.

17. Garcia-Pastor P, Randazzo A., Gomez-Paloma L, Alcaraz MJ, Paya $M$. Effects of petrosaspongiolide $M$, a novel phospholipase A2 inhibitor, on acute and chronic inflammation. J Pharmacol Exp Ther, 1999; 289:166-172.

18. Negrete $R$, Backhouse $N$, Cajıgal I, Delporte $C$, Cassels BK, Breitmaier E, Eckhardt G. Two new antiinflamatory elemanolides from Centaurea chilensis. J Ethnopharmacol, 1993; 40:149-153.
19. Kulkarni SK, Mehta AK, Kunchandy J. Antiinflammatory actions of clonidine, guanfacine and $B-H T 920$ against various inflammageninduced acute paw oedema in rats. Arch Int Pharmacodyn Ther, 1986; 279:324-334.

20. Nishizuka $Y$. The role of protein kinase $C$ in cell surface signal transduction and tumour promotion. Nature, 1988; 334:661-665.

21. Negrete R, Backhouse N, Avendano S, San Martin A. Dehydrocostus lactone and $8 \beta$ hydroxydehydrocostus lactone in Centaurea chilensis Hook and Arn. Planta Med, 1984; 18:226-232.

22. Garbacki N, Gloaguen V, Damas J, Bodart P, Tits M, Angenot L. Anti-inflamatory and immunological effects of Centaurea cyanus flower-heads. J Ethnopharmacol, 1999; 68:235-241.

23. Karamenderes $C$, Konyalioglu S, Khan S, Khan I. Total phenolic contents, free radical scavenging activities and inhibitory effects on the activation of NF-kappa B of eight Centaurea L. species. Phytother Res, 2007; 21:488-491. 